\title{
Alopecia Areata: An Autoimmune Disease of Multiple Players
}

\section{Poonkiat Suchonwanit (D) Chaninan Kositkuljorn (D) Cherrin Pomsoong (D)}

Division of Dermatology, Department of Medicine, Faculty of Medicine, Ramathibodi Hospital, Mahidol University, Bangkok, Thailand
Correspondence: Poonkiat Suchonwanit Division of Dermatology, Department of Medicine, Faculty of Medicine,

Ramathibodi Hospital, Mahidol University, 270 Rama VI Road, Ratchathewi, Bangkok, 10400, Thailand

Tel +66-2-20I I I4I

Fax +66-2-20I-I2II ext 4

Email poonkiat@hotmail.com

\begin{abstract}
Alopecia areata (AA) is an autoimmune disease of the hair follicles. It is characterized by a well-defined non-scarring alopecic patch or patches that may extend to the entire scalp or lead to total body hair loss. Due to its unpredictable clinical course, AA causes substantial psychological harm. Despite the high prevalence of this disease and extensive research, its exact pathomechanism is unclear, and current treatments have a high relapse rate that has deemed AA incurable. Over the past few decades, researchers have investigated multiple potential factors that may help alleviate its pathogenesis and provide effective treatment. Given its complex immunopathogenesis, AA is considered an autoimmune disease with multiple factors. This review gathers current evidence that emphasizes molecular mechanisms, possible causative etiologies, and targeted immunotherapies for AA. Understanding its underlying mechanisms may shed light on new strategies to effectively manage AA in the future.
\end{abstract}

Keywords: alopecia totalis, alopecia universalis, autoimmunity, hair loss, inflammation

\section{Introduction}

Alopecia areata (AA) is an immune-mediated hair loss disorder that affects $1.7 \%$ of the general population. Its prevalence ranges from $0.1-0.2 \%$ worldwide. ${ }^{1}$ AA's manifestations vary, from a well-defined alopecic patch, multiple patches, total scalp alopecia (alopecia totalis, AT), to complete body hair loss (alopecia universalis, AU). ${ }^{2}$ The disease impacts quality of life and has major psychological effects for men and women, especially in social acceptance and psychological well-being. ${ }^{3}$

AA is diagnosed upon physical examination and trichoscopy; however, a scalp biopsy may also be performed in undecided cases. ${ }^{4,5}$ Histopathological features of acute AA include hair follicle (HF) peribulbar lymphocytic infiltration, with perifollicular $\mathrm{CD}^{+}{ }^{\mathrm{T}}$ cells and intrafollicular $\mathrm{CD}^{+}{ }^{\mathrm{T}}$ cells. ${ }^{6}$ In chronic AA there is an increase in miniaturized hairs situated in the papillary dermis with peribulbar lymphocytic infiltration. ${ }^{7,8}$ Immunosuppressive agents such as systemic corticosteroids, cyclosporine, and contact immunotherapy highlight the autoimmune nature of AA, as patients exhibit marked improvement after administration of these agents. ${ }^{9}$

Although much research into AA has been conducted, its exact pathomechanisms are unknown. Emerging evidence suggests that a collapse in HF immune privilege (IP) is the leading cause of AA. When this process develops, HFs present surface autoantigens, resulting in inflammatory cells attacking HFs and eventually resulting in an alopecic patch. Other factors such as genetics, stress, and environment are also responsible for development of $\mathrm{AA} .{ }^{10} \mathrm{AA}$ is considered an 
autoimmune disease with multiple players and a complex immunopathogenesis. This review explores the molecular mechanisms involved in the pathogenesis of AA, its associated factors, and current immunotarget therapies. We integrate all existing evidence to gain insights into AA immunopathogenesis and its immunotherapeutic options.

\section{Hair Follicle Immune Privilege Collapse}

The hair growth cycle is divided into three phases: anagen (growth stage), catagen (transition stage), and telogen (resting stage). When telogen hairs are shed, new anagen hairs grow to replace them, beginning a new cycle. ${ }^{11-13}$ Current evidence suggests that the collapse of IP in HF is the principal event in AA pathogenesis. Currently, the concept of IP is believed to be a major factor in immune tolerance, particularly in the brain, eyes, gonads, fetomaternal placenta, and HFs. IP acts by suppressing immune-mediated inflammation and favoring immune tolerance from harmful effects of inappropriate immune recognition. ${ }^{14}$ In the hair bulge, proximal HF epithelia exhibit an IP area during anagen. ${ }^{15}$ IP protects epithelial stem cells, which are essential for remodeling capacity and HF regeneration. A previous study supported these hypotheses using a murine model for skin graft transplantation. It was observed that despite the rejection of epidermal pigment changes, donor HF melanocytes survived and evaded immune rejection. ${ }^{16}$

IP protects HF components from immune attacks by various mechanisms. Physical barriers, including the extracellular matrix, have reduced lymphatic permeability and guard hair bulbs against infiltrating immune cells. ${ }^{15,17}$ It also downregulates major histocompatibility complex (MHC) class I expression and MHC class I pathway molecules ( $\beta 2$-microglobulin and transporter associated with antigen processing [TAP-2]). Downregulation of MHC class I is caused by the local production of immunosuppressive factors, such as $\alpha$ melanocyte-stimulating hormone ( $\alpha-\mathrm{MSH})$, transforming growth factor- $\beta$ (TGF- $\beta$ ), indoleamine-2,3-dioxygenase (IDO), protein red encoded by IK gene (red/IK), interleukin (IL)-10, calcitonin gene-related peptide, insulinlike growth factor-1, and somatostatin. ${ }^{18,19}$ Reduction of MHC class II expression on HF Langerhans cells impairs antigen-presenting cell (APC) function. ${ }^{20}$ In addition, IP expresses "no danger" signals using type-1 transmembrane glycoprotein CD200, which lowers APC activity and pro-inflammatory cytokines secretion. ${ }^{21}$
The IP environment normally suppresses natural killer (NK) cell activation by downregulating MHC class I chainrelated gene A (MICA) and UL16-binding protein (ULBP) in resident immune cells. These would otherwise bind to NKG2D-activating receptors on $\mathrm{CD} 8^{+} \mathrm{T}$ cells and NK cells inducing inflammation and damaging local tissues. Supporting evidence shows that there are few perifollicular NK cells in healthy HFs. ${ }^{22}$ Next, killer cell Ig-like receptors (KIRs), which are MHC class I inhibitory receptors, were significantly higher in controls than in AA patients. ${ }^{23}$ KIRs help NK cells distinguish between normal cells and target cells, which prevents damage to healthy cells. Lastly, macrophage migration inhibitory factor, a pleiotropic cytokine presented in several IP sites, prevents the release of cytolytic perforin granules from NK cells. ${ }^{24}$

The HF IP environment is highly regulated and usually prevents autoimmune hair loss. Emerging evidence suggests that the collapse of HF IP contributes to AA pathogenesis. MHC class I and class II expression on the hair matrix and follicular epithelium are found in AA-affected patients. $^{20}$ The local production of immunosuppressive factors including $\alpha-\mathrm{MSH}$, TGF- $\beta$, IDO, and red/IK are downregulated in peri-lesional and lesional $\mathrm{AA}^{25,26}$ Histological features from AA patient scalp biopsies showed infiltrating peri-follicular $\mathrm{CD}^{+} \mathrm{T}$ cells, intrafollicular $\mathrm{CD} 8^{+} \mathrm{T}$ cells, ${ }^{6}$ mast cells, ${ }^{27} \mathrm{NK}$ cells, ${ }^{23}$ and APCs. ${ }^{28}$ MICA immunoreactivity occurred throughout AA-affected HFs, which activated $\mathrm{NKG}_{2} \mathrm{D}^{+} \mathrm{NK}$ cells and $\mathrm{CD} 8^{+} \mathrm{T}$ cells around AA lesions, but not in normal HFs. ${ }^{23}$

\section{Overview of Immune System Activation in Alopecia Areata}

Cytotoxic CD8+NKG2D+ T cells and interferon- $\gamma$ (IFN$\gamma$ ) have been demonstrated to play an important role in the development of AA. CD8+NKG2D+ T cells infiltrate the hair follicle of AA, initiating an IFN- $\gamma$ response and upregulation of $\gamma$-chain $\left(\gamma_{c}\right)$ cytokines, especially IL-2 and IL-15. ${ }^{29}$ These immune responses interfere with the maintenance of the HF IP by inducing ectopic expression of MHC molecules and the NKG2D ligands in the HF and promote the activation and survival of $\mathrm{CD} 8$ + NKG2D + T cells. Concurrently, several immune pathways are also responsible for the autoreactivity in AA, Figure 1 outlines activation of the immune system in AA. The following section provides a summary of all relevant factors involved in AA pathogenesis including 


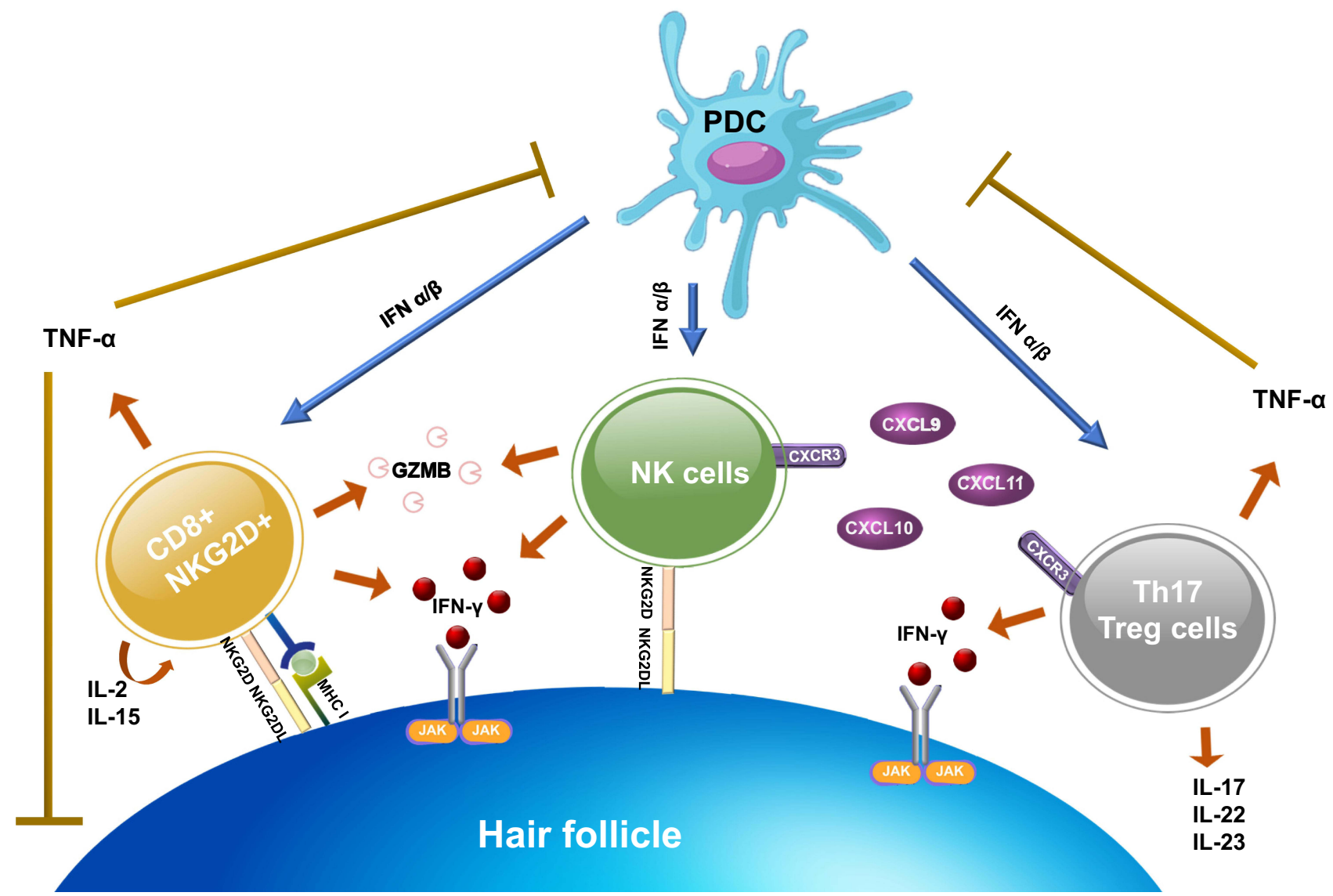

Figure I Immune system activation in AA. After the NKG2D receptor is recognized by the NKG2D associated ligands (MICA, ULBP3, and ULBP6), it promotes aggregation of $\mathrm{CD}^{+} \mathrm{NKG} 2 \mathrm{D}^{+} \mathrm{T}$ cells. Activated $\mathrm{CD} 8^{+} \mathrm{NKG} 2 \mathrm{D}^{+} \mathrm{T}$ cells mainly produce IFN- $\gamma$ to upregulate MHC class I and II expression via the JAK-STAT pathway and generate GZMB to induce apoptotic cell death. Concurrently, CD8 ${ }^{+} N K G 2 D^{+}$T cells increase an upregulation of $\gamma$-chain cytokines (IL-2 and IL-I5), which create a positive feedback loop by promoting the activation of IFN- $\gamma$-producing $C D 8^{+} N K G 2 D^{+} T$ cells. NK cells and CD4 ${ }^{+} \mathrm{T}$ cell subtypes (ThI7 and T reg cells) also produce IFN- $\gamma$. NK cells attack hair follicles upon the binding of NKG2D ligand to NKG2D receptor and through CXCR3 ligands expression (CXCL9, CXCLI0, and CXCLII). While CD4 ${ }^{+} \mathrm{T}$ cell subtypes, initiated by upregulation of MHC class II, trigger several pro-inflammatory cytokines and chemokines. PDCs play a role in the pathogenesis by producing a large amount of type I IFN to enhance the activation of $\mathrm{CD} 8^{+}, \mathrm{CD} 4^{+}$, and NK cells. However, TNF- $\alpha$, created by $\mathrm{CD} 4^{+}$and $\mathrm{CD} 8^{+} \mathrm{T}$ cells, also have negative effects by suppressing PDCs activity and interfering with the keratinocytes differentiation.

Abbreviations: AA, alopecia areata; CXCL, chemokine (C-X-C motif) ligand; CXCR3, C-X-C Motif Chemokine Receptor 3; GZMB, granzyme B; IFN, interferon, IL, interleukin; JAK, Janus kinase; MHC, major histocompatibility complex; MICA, major histocompatibility complex class I chain-related gene A; NK, natural killer; PDCs, plasmacytoid dendritic cells; Treg cells, regulatory T cells; STAT, signal transducer and activator of transcription; Th cells, T-helper cells; TNF, tumor necrosis factor; ULBP, ULI6-binding protein.

autoantigens, immune cells, cytokines, T helper 2 (Th2) response, genetics, stress, and environment.

\section{Autoantigens}

Two studies affirmed the hypothesis that a dysregulation in immune system homeostasis contributes to the development of $\mathrm{AA} . \mathrm{C} 3 \mathrm{H} / \mathrm{HeJ}$ mouse models were used to demonstrate hair loss after full-thickness skin grafts from normal mice to AA-affected mice. ${ }^{30}$ In addition, grafting AA-affected scalps onto severe combined immunodeficient (SCID) mice resulted in hair growth. ${ }^{31}$ Although these models implicated T cells within the skin grafts in triggering immune activation, the involvement of autoantigens in cytotoxic T cell responses and disease development are still inconclusive.
AA specifically occurs during the anagen phase of hair growth, where HF melanocytes, keratinocytes, and dermal fibroblasts are the assumed targets of autoreactive cytotoxic $\mathrm{T}$ cells. The evidence for melanocyte-related peptides being autoantigens can be seen in numerous studies. Melanocytederived epitopes, including the melanoma antigen and glycoprotein 100, were recognized by T cells and contributed to hair loss in human AA scalp grafted onto SCID mice. ${ }^{32}$ Protein identification by mass spectrometry revealed that keratinocyte-derived trichohyalin and tyrosinase-related protein-2 promoted significantly greater cytotoxic $\mathrm{T}$ cell response compared with healthy controls. ${ }^{33,34}$ Moreover, the fact that AA preferentially targets pigmented hair over non-pigmented hair, in addition to the preferential regrowth 
of white hair after treatment, provides the best evidence to support the essential role of melanocyte-related peptides as autoantigens in $\mathrm{AA}^{35-37}$

\section{Immune Cells CD8+NKG2D+ T Cells}

$\mathrm{CD}^{+} \mathrm{NKG}^{+} \mathrm{D}^{+} \mathrm{T}$ cells are key regulators of $\mathrm{AA}$ pathogenesis. ${ }^{29,38-40}$ As NKG2D is an activating receptor expressed in both $\mathrm{NK}$ cells and $\mathrm{CD} 8^{+} \mathrm{T}$ cells, $\mathrm{CD}^{+} \mathrm{NKG}^{+} \mathrm{D}^{+} \mathrm{T}$ cells recognize the NKG2D ligands (MICA, ULBP3, and ULBP6), which upregulate MHC expression and contribute to HF IP collapse. Research has been conducted to determine if $\mathrm{CD} 8{ }^{+} \mathrm{NKG} 2 \mathrm{D}^{+}$ $\mathrm{T}$ cells initiate $\mathrm{AA}{ }^{29,38-40} \mathrm{~A}$ study using $\mathrm{C} 3 \mathrm{H} / \mathrm{HeJ}$ mice showed the AA-affected scalp lesions were infiltrated by $\mathrm{CD}^{+}{ }^{+} \mathrm{NKG} 2 \mathrm{D}^{+} \mathrm{T}$ cells. Flow cytometry data on the leukocyte populations also reported a significant increase in $\mathrm{CD}^{+} \mathrm{NKG}^{+} \mathrm{D}^{+} \mathrm{T}$ cells and total cellularity in AAaffected mice compared to controls. ${ }^{27,41}$

Specifically, measurements of AA lesional skin gene expression signatures indicate HF cytotoxic T cell infiltration, increased production of IFN- $\gamma$, and the upregulation of several $\gamma_{c}$ cytokines that promote the activation and survival of IFN- $\gamma$-producing $\mathrm{CD} 8{ }^{+} \mathrm{NKG} 2 \mathrm{D}^{+} \mathrm{T}$ cells. ${ }^{29}$ IL-2 and IL-15 are cytokines known to stimulate autoreactive T cells. When injected into human scalp grafted onto SCID mice, IL-2 stimulated $\mathrm{CD} 8^{+} \mathrm{NKG}^{2} \mathrm{D}^{+} \mathrm{T}$ cells and demonstrated clinical and histological features of $\mathrm{AA}^{42}$ Serum IL-15 levels in AA patients were significantly higher than in control group, and there was a positive correlation between serum levels and severity. ${ }^{43}$ Biopsies of AA scalp lesions demonstrated increases in IL-2 and IL-15 expression compared to non-lesional scalps. ${ }^{44}$ Notably, blocking the production of these proinflammatory cytokines suppressed AA progression and reduced the accumulation of $\mathrm{CD}^{+} \mathrm{NKG}^{-\mathrm{D}^{+}} \mathrm{T}$ cells in $\mathrm{C} 3 \mathrm{H} / \mathrm{HeJ}$ grafted mice. ${ }^{29}$ Lastly, granzyme B (GZMB) levels, an apoptogenic effector produced by cytotoxic cells, were elevated in both AA-affected $\mathrm{C} 3 \mathrm{H} / \mathrm{HeJ}$ mouse models and human HFs. ${ }^{45,46}$ These experiments demonstrated that $\mathrm{CD} 8^{+} \mathrm{NKG} 2 \mathrm{D}^{+} \mathrm{T}$ cells could induce AA.

\section{T Helper 17 and Regulatory T Cells}

Several autoimmune diseases, including AA, are associated with the $\mathrm{CD} 4^{+}$subtypes called $\mathrm{Th} 17$ and regulatory $\mathrm{T}$ (Treg) cells. ${ }^{47,48}$ After the upregulation of MHC class II, $\mathrm{CD}^{+} \mathrm{T}$ cells were found abundant in the dermis and around HFs. ${ }^{48}$ Th17 cells secrete the pro-inflammatory cytokines IL-17, IL-22, and IL-23, which induce inflammation and contribute to autoimmunity, ${ }^{49}$ whereas Treg cells suppress excessive lymphocyte activity to prevent autoimmune reactions. ${ }^{50}$ Using quantitative real-time polymerase chain reaction, increased IL-17 and IL-22 levels in affected scalp were found to have a positive correlation with disease severity. ${ }^{51}$ In addition, human Th17 cells also readily produced IFN- $\gamma$, resulting in promoting autoimmunity. ${ }^{52}$ It is suggested that increased Th17 levels and decreased Treg levels are proinflammatory and can induce local autoimmune reactivity. ${ }^{53}$ Studies also showed that Th17 levels were higher during active disease than when it is dormant, ${ }^{46}$ while Treg levels were higher in severe AA patients than in mild AA patients. ${ }^{54}$

\section{Plasmacytoid Dendritic Cells}

The role of plasmacytoid dendritic cells (PDCs) in AA pathogenesis is the subject of intensive study. They express the cell surface markers CD4, CD123, human leukocyte antigen (HLA)-DR, blood-derived dendritic cell antigen-2 (BDCA-2), Toll-like receptor (TLR) 7, and TLR9 within endosomal compartments. After the activation of TLR7 and TLR9, PDCs generate large amounts of type I IFN (IFN- $\alpha /$ IFN- $\beta$ ) approximately 1000 times higher than other cell types. ${ }^{55,56}$

PDCs regulate myeloid dendritic cells, CD4, CD8, NK, and $\mathrm{T}$ cell functions, thus, linking innate and adaptive immune responses. ${ }^{57}$ This is demonstrable in AA, where intradermal injections of PDCs into $\mathrm{C} 3 \mathrm{H} / \mathrm{HeJ}$ mice were found to contribute to AA development. ${ }^{28}$ Immunohistochemical analysis revealed the presence of a specific PDC marker, anti-BDCA-2, in the peribulbar regions in all cases. Moreover, intense and diffuse expression of MxA, an indirect marker of PDC activity, was observed in the hair bulbs and peribulbar regions of AAaffected patients. ${ }^{55}$

\section{Cytokines}

\section{IFN- $\gamma$}

As mentioned above, IFN- $\gamma$ has been implicated in the development of AA, being a critical Th1 effector cytokine in AA pathogenesis. It is mainly produced by NK and natural killer $\mathrm{T}$ (NKT) cells. In the anagen phase hair bulb, IFN- $\gamma$ specifically drives immune response by upregulating the expression of MHC I, NKG2D receptors, and 
chemokine (C-X-C motif) ligands (CXCLs) in HFs. ${ }^{38,39,58}$ A positive feedback autoreactivity of IFN- $\gamma$-producing cells resulted in maintaining lymphocytic infiltration and inducing Th1 activities, followed by increasing the disease duration and progression. ${ }^{29}$ Sundberg et al administered IFN- $\gamma$ to $\mathrm{C} 3 \mathrm{H} / \mathrm{HeJ}$ mice and observed AA-like characteristics over the next 36 days. ${ }^{59}$ Similarly, an experimental study failed to transfer AA-affected skin grafts from $\mathrm{C} 3 \mathrm{H} /$ $\mathrm{HeJ}$ mice to IFN- $\gamma$-deficient mice. ${ }^{60}$

Semiquantitative reverse-transcriptase PCR (RT-PCR) revealed that IFN- $\gamma$ mRNA was significantly increased in AA skin than in normal skin. ${ }^{61}$ Inhibiting cytokine signaling 3, a potent regulator of cytokine signaling, suppressed AA by inhibiting $\mathrm{CD}^{+} \mathrm{T}$ cells from producing IFN $-\gamma{ }^{35}$ Administering IFN- $\gamma$ antibodies inhibited AA development in graft recipients. ${ }^{29}$ Serum IFN- $\gamma$ levels also positively correlated with the degree of inflammation and severity of AA. ${ }^{62}$ All evidence indicates that even IFN- $\gamma$ alone may cause HF IP collapse.

IFN- $\gamma$ has also been proposed to inhibit the Janus kinase (JAK)/signal transducer and activator of transcription (STAT) pathways. This inhibits angiogenesis and stem cell proliferation and activation in the HF, which results in balding. ${ }^{63}$ An in vitro study using cultured dermal sheath cells from $\mathrm{C} 3 \mathrm{H} / \mathrm{HeJ}$ mice showed that exogenous IFN- $\gamma$ enhanced STAT1 activation. ${ }^{29}$ It also suggested that IFN- $\gamma$ can influence JAK/STAT signaling to prematurely terminate the anagen phase in HFs. ${ }^{39,58}$

\section{TNF- $\alpha$}

Another pro-inflammatory cytokine implicated in AA pathogenesis is tumor necrosis factor (TNF)- $\alpha$. It is secreted primarily by $\mathrm{CD}^{+}$and $\mathrm{CD} 8^{+} \mathrm{T}$ cells and has potent anti-proliferative effects on epithelial cells and keratinocytes. ${ }^{64,65}$ In HFs, TNF- $\alpha$ interferes with the hair growth cycle, contributing to catagen morphology. ${ }^{66-69}$ It suppresses PDC development and dysregulates IFN- $\alpha$ production. ${ }^{55,70}$ TNF- $\alpha$ induces both IFN- $\alpha$ and IFN- $\gamma$ production, while interfering with keratinocyte differentiation and the hair growth cycle.

\section{CXCR3}

The C-X-C Motif Chemokine Receptor 3 (CXCR3) and its ligands CXCL9, CXCL10, and CXCL11 are chemokine products of IFN-induced inflammation. ${ }^{46,71}$ CXCR3 is mainly expressed on $\mathrm{Th} 1, \mathrm{CD}^{+}{ }^{+} \mathrm{T}$ cells, $\mathrm{CD} 8^{+} \mathrm{T}$ cells, NK, and NKT cells, while resident cells, including dendritic cells, secrete CXCR3 ligands. These chemokines induce Th1-mediated immune responses by promoting infiltration of cytotoxic T lymphocytes, NK cells, NKT cells, and macrophages into HFs. ${ }^{71,72}$ Some of these cells also produce IFN- $\gamma$, creating a positive feedback loop by stimulating the production of CXCL9, CXCL10, and CXCL11. ${ }^{71}$ Significant increases in CXCR3 and its ligands were detected using RT-PCR in 10-week skin grafts where AA was induced. ${ }^{46}$ CXCR3 was also found to be upregulated in effector $\mathrm{T}$ cells derived from AA skin lesion, while the epithelial cells showed an increase in CXCR3 ligand expression compared to that in healthy tissues. Moreover, inhibition of CXCR3 function with blocking antibodies alleviated AA development in skin grafted mice. ${ }^{73}$

\section{Role of the Th2 Response}

In addition to Th1, Th2 immune responses are also regulated by the cytokine pathways involved in AA pathogenesis. ${ }^{44,74}$ Both Th1 and Th2 cytokine expression have been demonstrated in animal models of $\mathrm{AA}^{75}$ Moreover, the significant association between AA and atopic diseases, a group of conditions providing predominant Th2-type inflammation, also supports Th2 involvement in AA. ${ }^{76}$ Though Th2 immune responses are not the primary pathomechanisms of AA, Th2 detection distinguishes between AA variants, predicts the prognosis, and evaluates treatment efficacy. Th2-dependent expression, comprising IL-4, IL-5, IL-6, immunoglobulin (Ig) E, C-C motif chemokine ligand (CCL) 17, IL-13, IL-31, CCL13, CCL17, CCL18, CCL22, and CCL26, was detected in AA patients. ${ }^{74,77-80}$ A prior study found that chronic AA or AU patients had higher serum IgE and IL-4 levels than those in healthy controls. ${ }^{77}$ The Th2 cytokines IL-13, CCL18, and CCL26 were significantly upregulated in AA lesions. ${ }^{74}$ Song et al observed IL-13, CCL13, CCL17, CCL22, and CCL26 expression (all Th2-related cytokines) were increased in AA, and that AA severity was positively correlated with IL-13 and CCL13 expression. ${ }^{78}$ Serum CCL17 is also significant, as it is low in patients that respond to AA treatments, moderate in mild AA, and high in severe AA. ${ }^{79}$

\section{Role of Genetics}

AA development appears to have a genetic predisposition. The heritable incidence of AA ranges from $10 \%-42 \% .{ }^{81-84}$ The estimated lifetime risk is $\sim 5 \%-8 \%$ among first-degree relatives and $42 \%-55 \%$ in identical twins. ${ }^{85-88}$ A person's genetic susceptibility to AA is mainly conferred by HLA alleles, especially the DQB and DR alleles in chronic AT/ 
AU. ${ }^{89}$ In murine models, genetic AA susceptibility was found in chromosomes 17 (Alaa1), 9 (Alaa2), 8 (Alaa3), and 15 (Alaa4). Only the Alaal site on $\mathrm{C} 3 \mathrm{H} / \mathrm{HeJ}$ mice, a strain that spontaneously develops an adult-onset form of AA, matched with the HLA locus in humans. ${ }^{90}$ Additionally, non-HLA candidate genes, such as the MICA, influence AA susceptibility. ${ }^{91}$

Genome-wide association studies reported an association between genetic variants and AA. The data identified variations in several genes controlling Treg cell activation and proliferation, including cytotoxic $\mathrm{T}$ lymphocyte-associated antigen 4, IL-2/IL-21, IL-2 receptor A (IL-2RA; CD25), and Eos (Ikaros family zinc finger 4; IKZF4). Regions containing genes expressed in the HF itself (PRDX5 and STX17), were associated with AA development. This study also demonstrated that ULBP3 gene upregulation on chromosome 6q25.1 are NKG2D-activating ligands. ${ }^{92}$ Furthermore, a follow-up study identified IL13 and KIAA0350 as susceptible loci for AA. ${ }^{93}$ Lastly, the gene encoding the lymphoid protein tyrosine phosphatase (PTPN22), which normally suppresses T-cell proliferation, and IL-1 cluster genes (IL-1 receptor antagonist) were associated with severe forms of AA. ${ }^{94}$

\section{Role of Stress}

Psychological stress activates the brain-HF (BHA) and hypothalamic-pituitary-adrenal (HPA) axes. In BHA, the neuropeptide substance $\mathrm{P}$ (SP), released from sensory nerve fibers, is one of the most effective mediators in perifollicular mast cell activation. It inhibits hair growth during anagen and facilitates $\mathrm{HF}$ regression during catagen. $^{95,96}$ Nerve growth factor (NGF), a potent SP releaser, triggers HF keratinocyte apoptosis and downregulates keratinocyte growth factor expression. ${ }^{97}$ Both mediators cause neuroinflammation and result in perifollicular mast cell degranulation and APC accumulation.

Psychological stress also activates the HPA axis, resulting in the secretion of corticotropin-releasing hormone $(\mathrm{CRH})$, a neuropeptide hormone involved in systemic stress responses. In human $\mathrm{HFs}, \mathrm{CRH}$ promotes the degranulation of mast cells, which releases histamine, TNF- $\alpha$, IL-6, and IL-1 into the microenvironment, promoting neuroinflammation. ${ }^{98-101}$ Thus, stress-induced neuroendocrine factors, including SP, NGF, and $\mathrm{CRH}$, contribute to perifollicular neurogenic inflammation followed by the collapse of IP in the HFs. ${ }^{14}$

\section{Role of Environment}

Although immunogenetics are the principal factors affecting patient susceptibility to AA, environmental factors including viral infections, trace elements or micronutrients, immunization, and allergies are also thought to influence the disease. After viral infection, Th1 immune responses result in supraphysiologic IFN production. Using RT-PCR, Skinner et al detected cytomegalovirus (CMV) DNA in scalp biopsy specimens from AA patients, but not in other hair and scalp diseases. ${ }^{102}$ Nevertheless, further study using in situ hybridization failed to produce a correlation between $\mathrm{CMV}$ and AA. ${ }^{86,103}$ In self-reports of prior Epstein-Barr virus (EBV) infection, 12 of 6256 individuals developed AA within 6 months of experiencing EBV infection. ${ }^{104}$ Swine flu virus was also reported to induce AA by the overproduction of IFN- $\gamma$, contributing to Th1 immune hyperactivity. ${ }^{105}$

A deficiency of trace elements and micronutrients in the diet may also trigger the onset of AA by disrupting immune functions. Zinc, selenium, folate, and vitamin $\mathrm{D}$ deficiencies have been suggested to influence AA onset. In one meta-analysis, serum levels of zinc and selenium were significantly lower in AA patients than in controls. ${ }^{106}$ Moreover, zinc levels were inversely correlated with disease duration, the severity of AA, and its resistance to therapies. ${ }^{107}$ In a recent review, serum folate and vitamin D levels were lower in AA patients when compared to healthy participants. However, inconsistent results were found, and additional research may be required.

Research into vaccination-induced AA is inconclusive. One study reported an association between immunization, especially the hepatitis vaccine, and AA. ${ }^{108,109}$ A case series indicated that the recombinant hepatitis $B$ vaccine was associated with AA. ${ }^{108}$ The results of a study using a $\mathrm{C} 3 \mathrm{H} / \mathrm{HeJ}$ mouse model also supported this finding that clinical AA developed in older female mice shortly after hepatitis B vaccination. ${ }^{109}$

Atopic diseases such as allergic rhinitis, asthma, and atopic dermatitis are also recognized as pathogenic events in AA. Several studies demonstrated a significant association between AA and atopic diseases. ${ }^{76,110,111}$ A retrospective study found that $38.2 \%$ of AA patients had allergic diseases. ${ }^{110}$ The data from a matched casecontrol study revealed AA patients had a significantly higher prevalence of atopic diseases than control subjects. ${ }^{111} \mathrm{Li}$ et al detected higher percentages of total 
$\operatorname{IgE}$ and dust mite-specific IgE antibodies in patients with early-onset and severe AA. ${ }^{12}$

\section{Immunotherapies}

Current therapeutic modalities for AA include corticosteroids, topical minoxidil, anthralin, cyclosporine, photochemotherapy, and contact immunotherapies. ${ }^{113,114}$ Since there are no Food and Drug Administration-approved medications for AA, several targeted immune therapies have been developed in recent years as new treatment options. Pathogenetic factors and immunotherapies of AA are summarized in Table 1. Understanding the molecular mechanisms of AA permits new insight for developing novel treatments. Some of which have achieved remarkable clinical results. Herein, we summarized all immune-modulating treatments for AA.

\section{Contact Immunotherapies}

Diphenylcyclopropenone (DPCP) and squaric acid dibutyl ester are currently considered effective modalities for inducing hair growth. After the allergic reaction induced by these substances, suppressor $\mathrm{T}$ cells are recruited and express $\mathrm{CD}^{+}$and $\mathrm{CD}^{2} \mathrm{a}^{+}$, which inhibit APC migration in affected HFs. Moreover, an alteration of cytokine expression levels is observed after treatment. Serum IL-2, IL-4, IL-8, IL-10, and TNF- $\alpha$ levels are increased after administering topical immunotherapies, whereas serum IFN- $\gamma$, IL-12, and Th17 cytokine expression are decreased. ${ }^{115-118}$ Happle et al reported the efficacy of DPCP in 1983, ${ }^{119}$ and it has since gained popularity and is recommended as the first-line topical sensitizer for treating AA. ${ }^{120}$ In the literature, the efficacy of DPCP for hair regrowth ranges from $6 \%-77 \%{ }^{121}$ The use of DPCP combination therapy with anthralin, minoxidil, and imiquimod to enhance the therapeutic response was investigated, but a wide range of efficacies was reported. ${ }^{122-127}$ Additionally, since DPCP treatment protocols may take some time to achieve an acceptable treatment response for AA, modified protocols have since been established and have obtained satisfactory results. ${ }^{128-132}$

\section{Janus Kinase Inhibitors}

Recently, the efficacy of leveraging Janus Kinase inhibitors (JAKis) in various autoimmune and hematologic diseases has seen increased interest. JAKis are selective, competitive inhibitors of adenosine triphosphate-binding sites on JAK/STAT. ${ }^{133}$ It predominantly blocks the downstream IFN- $\gamma$ and $\gamma_{\mathrm{c}}$ cytokine receptors and reduces the recruitment of $\mathrm{CD}^{+} \mathrm{NKG}^{2} \mathrm{D}^{+} \mathrm{T}$ cells. ${ }^{29,134}$ It also interferes with Th1 cell and Th17 cell differentiation. Notably, activation and proliferation of HF stem cells are promoted by JAKis, which accelerates HF reentry into the anagen phase. ${ }^{135}$ Treatment of AA with JAK1/2 (IFN- $\gamma$ pathway) and JAK3 ( $\gamma_{c}$ cytokines) inhibitors showed promising results. The therapeutic efficacy of oral tofacitinib and oral ruxolitinib in treating severe and recalcitrant $\mathrm{AA}$ has an overall response rate of $30 \%-75 \%$, with transient and minimal side effects. ${ }^{63,136}$

\section{Lipid-Lowering Agents}

Besides their efficacy in reducing atherosclerotic cardiovascular risk, statins are also anti-inflammatory and immunomodulatory agents. In vitro and in vivo studies showed that statins downregulate Th1 cytokines and upregulate Th2 cytokines via modulation of the JAK/STAT pathway. Furthermore, it can directly modulate APCs to increase Treg cell activation. ${ }^{137}$ Evidence also suggests that statins downregulate leukocyte activation, proliferation, differentiation, adhesion, and extravasation into target tissues. ${ }^{138}$ The combination of statins and ezetimibe (non-statin lipid-lowering medication) showed promising results with $30 \%-80 \%$ hair regrowth in $28 \%$ of recalcitrant AA patients. ${ }^{139}$ However, another study reported unsatisfactory results as none of the patients achieved hair regrowth. ${ }^{140}$ The relapse rate was significantly lower in statin-treated patients than in the control group. ${ }^{141}$ Thus, lipid-lowering agents, when combined with other therapies, show promise for preventing disease relapses; however, further studies to elucidate this are required.

\section{Phosphodiesterase-4 Inhibitors}

Apremilast, a selective phosphodiesterase-4 (PDE4) inhibitor, has been shown to inhibit the production of IFN- $\gamma$ and downregulate target organ MHC class II expression. ${ }^{142}$ In humanized mouse models, the injection of apremilast into skin grafts decreased IFN- $\gamma$ and TNF- $\alpha$ production. ${ }^{143}$ Nonetheless, treatments on moderate to severe AA and recalcitrant AA showed unsatisfactory results as most patients failed to achieve hair regrowth. ${ }^{144,145}$ Despite the selective inhibition of PDE4, there is no evidence supporting the efficacy of apremilast in AA treatment.

\section{Interleukin 2}

IL-2 modulates Treg activity in vivo through a STATdependent mechanism. ${ }^{146}$ Castela et al investigated the efficacy of low-dose recombinant IL-2 injections in five severe AA patients. All patients showed partial hair regrowth without serious adverse events, and 
Table I Pathogenetic Factors and Targeted Immunotherapies of Alopecia Areata

\begin{tabular}{|c|c|c|c|}
\hline $\begin{array}{l}\text { Pathogenetic } \\
\text { Factors }\end{array}$ & Roles & Immunotherapies & Mechanism of Treatment \\
\hline Autoantigens & $\begin{array}{l}\text { - Stimulating autoreactive cytotoxic } \\
\text { T lymphocytes }\end{array}$ & - Not available & - \\
\hline \multicolumn{4}{|l|}{ Immune cells } \\
\hline \multirow[t]{2}{*}{$\begin{array}{l}-\mathrm{CD}^{+} \mathrm{NKG}^{+} \mathrm{D}^{+} \\
\mathrm{T} \text { cells }\end{array}$} & \multirow{2}{*}{$\begin{array}{l}\text { - Increasing the production of IFN- } \gamma \text { and } \gamma \text { - } \\
\text { chain cytokines via JAK/STAT pathway } \\
\text { - Inducing apoptotic cell death by producing } \\
\text { GZMB }\end{array}$} & - Anti-CD2 & $\begin{array}{l}\text { - Binding with } \mathrm{CD} 2 \text {, causing deactivation of } \mathrm{T} \text { cells } \\
\text { - Inducing apoptosis in both } \mathrm{CD} 4^{+} \text {and } \mathrm{CD} 8^{+} \\
\text {memory } \mathrm{T} \text { cells }\end{array}$ \\
\hline & & - Anti-CDI la & - Inhibiting $T$ cell activation and migration \\
\hline \multirow[t]{2}{*}{ - ThI7 cells } & \multirow[t]{2}{*}{$\begin{array}{l}\text { - Secreting proinflammatory cytokines (IL- } \\
\text { I7, IL-22, and IL-23) }\end{array}$} & $\begin{array}{l}\text { - Contact } \\
\text { immunotherapy }\end{array}$ & $\begin{array}{l}\text { - Decreasing the level of IFN- } \gamma \text {, IL-I2, and ThI7 } \\
\text { cytokines } \\
\text { - Reducing the inflammatory cells } \\
\text { - Disturbing APCs migration }\end{array}$ \\
\hline & & - Anti-IL-I2/IL-23 & $\begin{array}{l}\text { - Inhibiting ThI differentiation, proinflammatory } \\
\text { cytokines, and Th } 17 \text { cell proliferation }\end{array}$ \\
\hline \multirow[t]{2}{*}{ - Treg cells } & \multirow[t]{2}{*}{ - Suppressing excessive lymphocyte activity } & - Statins & $\begin{array}{l}\text { - Downregulating ThI cytokines and upregulating } \\
\text { Th2 cytokines via modulation of the JAK/STAT } \\
\text { pathway } \\
\text { - Increasing activated Treg cells } \\
\text { - Inhibiting of leukocyte adhesion and extravasation } \\
\text { into HF }\end{array}$ \\
\hline & & - Low-dose IL-2 & - Recruiting Treg cells (CD4+CD25+FoxP3+) \\
\hline - PDCs & $\begin{array}{l}\text { - Producing type I IFN (IFN- } \alpha \text { and } \beta \text { ) } \\
\text { through TLR7 and TLR9 stimulation }\end{array}$ & - Not available & - \\
\hline \multicolumn{4}{|l|}{ Cytokines } \\
\hline \multirow[t]{3}{*}{$-\mathrm{IFN}-\gamma$} & \multirow{3}{*}{$\begin{array}{l}\text { - Inducing MHC expression that stimulates } \\
\text { NKG2D receptors } \\
\text { - Signaling through JAK/STAT pathway which } \\
\text { helps promoting adaptive immune response }\end{array}$} & - JAKis & $\begin{array}{l}\text { - Terminating } \mathrm{T} \text { cell-mediated immune response } \\
\text { - Blocking IFN- } \gamma \text { signaling and } \gamma \text {-chain cytokines } \\
\text { - Restoring anagen phase of the hair follicle }\end{array}$ \\
\hline & & - PDE4 inhibitors & $\begin{array}{l}\text { - Reducing IFN- } \gamma \text { by upregulation of cAMP } \\
\text { - Downregulating MHC class II expression }\end{array}$ \\
\hline & & - Anti-IFN- $\gamma$ & $\begin{array}{l}\text { - Blocking IFN- } \gamma \text { which leads to the downregulation } \\
\text { of MHC expression and immune-cell recruitment }\end{array}$ \\
\hline- TNF- $\alpha$ & $\begin{array}{l}\text { - Providing anti-proliferative effect on } \\
\text { epithelial cells and keratinocytes } \\
\text { - Abrogating hair growth and inducing } \\
\text { catagen phase of HF } \\
\text { - Suppressing the development of PDCs }\end{array}$ & - Anti-TNF- $\alpha$ & $\begin{array}{l}\text { - Activating Treg cells } \\
\text { - Inhibiting proinflammatory cytokines such as IFN- } \gamma \text {, } \\
\text { IL-6, and IL-I }\end{array}$ \\
\hline - CXCR3 & $\begin{array}{l}\text { - Promoting Thl-mediated immune } \\
\text { responses by the accumulation of immune } \\
\text { cells }\end{array}$ & - Not available & - \\
\hline $\begin{array}{l}\text { Th2 immune } \\
\text { response }\end{array}$ & - Under investigation & - Not available & - \\
\hline
\end{tabular}

Abbreviations: APCs, antigen presenting cells; cAMP, cyclic adenosine monophosphate; CXCR3, C-X-C Motif Chemokine Receptor 3; GZMB, granzyme B; HF, hair follicle; IFN, interferon; IL, interleukin; JAK, Janus kinase; JAKi, Janus kinase inhibitors; MHC, major histocompatibility complex; NK, natural killer; PDCs, plasmacytoid dendritic cells; PDE, phosphodiesterase; Treg cells, regulatory T cells; STAT, signal transducer and activator of transcription; Th cells, T-helper cells; TNF, tumor necrosis factor; TLR, Toll-like receptor. 
immunochemical analysis revealed a significantly increased number of Treg cells in the majority of patients $(80 \%){ }^{147}$ One explanation for the partial hair growth response is that IL-2 not only suppresses autoimmune responses by Treg activation but also worsens AA by increasing NK cell activity. ${ }^{148}$

\section{Anti-IFN- $\gamma$ Antibodies}

Blocking major inflammatory cytokines may reduce MHC expression and immune cell recruitment. Anti-IFN- $\gamma$ therapy is proposed to treat several autoimmune diseases, including AA. AA patients observed hair regrowth after administration with anti-IFN- $\gamma$ antibodies, while AT and AU patients were non-responders. ${ }^{149}$

\section{Anti-TNF- $\alpha$}

The anti-TNF- $\alpha$ biologic, etanercept, blocks TNF- $\alpha-$ mediated processes. It functions to activate Treg cells and inhibit pro-inflammatory cytokines. Despite the theoretical benefit, various clinical trials showed it has undesirable effects. ${ }^{150}$ Moreover, some cases showed progressive balding due to activation of self-reactive $\mathrm{T}$ cells, which means that patients treated with anti-TNF $-\alpha$ may develop further immune-mediated skin lesions such as psoriasis, granuloma annulare, vasculitis, and AA. ${ }^{151,152}$

\section{Anti-IL-12/IL-23}

Ustekinumab is a human Ig monoclonal antibody that binds with the p40-subunit of IL-12 and IL-23. Blocking these cytokines downregulated Th1 differentiation, proinflammatory cytokines, and Th17 cell proliferation. ${ }^{153}$ However, minimal improvements in extensive AA and pediatric AA were noted, while other patients even reported developing AA after initiating ustekinumab. ${ }^{154-156}$

\section{Anti-CD2}

Alefacept is a recombinant fusion protein of lymphocyte function-associated antigen-3 (LFA-3) and an IgG dimer that acts to inactivate $\mathrm{T}$ cells by binding to $\mathrm{CD} 2$. It also induces apoptosis in both $\mathrm{CD} 4^{+}$and $\mathrm{CD} 8^{+}$memory effector T lymphocytes. ${ }^{157}$ There was a partial response after using alefacept in one patient. ${ }^{158}$ However, a randomized controlled trial (RCT) demonstrated unsuccessful treatment with an insignificant lowering of $\mathrm{CD}^{+}$count in severe AA patients. ${ }^{159}$

\section{Anti-CD I la}

Efalizumab inhibits the interaction of CD11a, which blocks T-cell activation and migration. In theory, it was proposed to attenuate AA. There are case reports of recalcitrant AT and long-standing AU patients that responded to efalizumab with no side effects. ${ }^{160,161}$ Nevertheless, in an $\mathrm{RCT}$, the results revealed no differences from placebo. ${ }^{162}$

\section{Conclusion}

Multiple immunomodulators are involved in the pathogenesis of AA, including autoantigens, inflammatory cells, cytokines, and chemokines. IP maintains the HF microenvironment to protect the regenerative capability of HFs. The collapse of HF IP is the key factor contributing to disease. While AA constitutes an example of autoimmune hair loss, the underlying causes of HF IP collapse may be more important. Despite the complex disease etiology and our incomplete understanding of the relationship between these factors and hair loss, we presume that genetic predisposition, stress, and environmental factors affect immune activation and influence AA occurrence. ${ }^{163-169}$ Further, novel targeted therapies that treat AA have been reviewed. However, a complete response without relapse remains challenging. Understanding the underlying mechanisms may shed light on our future understanding of AA pathogenesis as well as new and effective strategies for the management of this disease.

\section{Disclosure}

The authors report no conflicts of interest in this work.

\section{References}

1. Safavi K. Prevalence of alopecia areata in the first national health and nutrition examination survey. Arch Dermatol. 1992;128(5):702. doi:10.1001/archderm.1992.01680150136027

2. Tan E, Tay YK, Goh CL, Chin Giam Y. The pattern and profile of alopecia areata in Singapore--a study of 219 Asians. Int J Dermatol. 2002;41(11):748-753. doi:10.1046/j.1365-4362.2002.01357.x

3. Cash TF. The psychology of hair loss and its implications for patient care. Clin Dermatol. 2001;19(2):161-166. doi:10.1016/S0738-081X (00)00127-9

4. Khunkhet S, Vachiramon V, Suchonwanit P. Trichoscopic clues for diagnosis of alopecia areata and trichotillomania in Asians. Int J Dermatol. 2017;56(2):161-165. doi:10.1111/ijd.13453

5. Leerunyakul K, Suchonwanit P. Asian hair: a review of structures, properties, and distinctive disorders. Clin Cosmet Investig Dermatol. 2020;13:309-318. doi:10.2147/CCID.S247390

6. Perret C, Wiesner-Menzel L, Happle R. Immunohistochemical analysis of T-cell subsets in the peribulbar and intrabulbar infiltrates of alopecia areata. Acta Derm Venereol. 1984;64(1):26-30.

7. Whiting DA. Histopathologic features of alopecia areata: a new look. Arch Dermatol. 2003;139(12):1555-1559. doi:10.1001/archderm.13 9.12.1555 
8. Stefanato CM. Histopathology of alopecia: a clinicopathological approach to diagnosis. Histopathology. 2010;56(1):24-38. doi:10.1111/j.1365-2559.2009.03439.x

9. Suchonwanit P, Kositkuljorn C, Mahasaksiri T, Leerunyakul K. A comparison of the efficacy and tolerability of three corticosteroid treatment regimens in patients with alopecia areata. $J$ Dermatolog Treat. 2020;1-6. doi:10.1080/09546634.2020.1773384

10. Ikeda T. Produced alopecia areata based on the focal infection theory and mental motive theory. Dermatologica. 1967;134 (1):1-11. doi:10.1159/000254233

11. Meephansan J, Thummakriengkrai J, Ponnikorn S, Yingmema W, Deenonpoe R, Suchonwanit P. Efficacy of topical tofacitinib in promoting hair growth in non-scarring alopecia: possible mechanism via VEGF induction. Arch Dermatol Res. 2017;309 (9):729-738. doi:10.1007/s00403-017-1777-5

12. Chanasumon N, Sriphojanart T, Suchonwanit P. Therapeutic potential of bimatoprost for the treatment of eyebrow hypotrichosis. Drug Des Devel Ther. 2018;12:365-372. doi:10.2147/DDDT.S156467

13. Rojhirunsakool S, Suchonwanit P. Parietal scalp is another affected area in female pattern hair loss: an analysis of hair density and hair diameter. Clin Cosmet Investig Dermatol. 2018;11:7-12. doi:10.2147/CCID.S153768

14. Azzawi S, Penzi LR, Senna MM. Immune privilege collapse and alopecia development: is stress a factor. Skin Appendage Disord. 2018;4(4):236-244. doi:10.1159/000485080

15. Paus R, Ito $\mathrm{N}$, Takigawa $\mathrm{M}$, Ito $\mathrm{T}$. The hair follicle and immune privilege. J Investig Dermatol Symp Proc. 2003;8(2):188-194. doi:10.1046/j.1087-0024.2003.00807.x

16. Barker CF, Billingham RE. Analysis of local anatomic factors that influence the survival times of pure epidermal and full-thickness skin homografts in guinea pigs. Ann Surg. 1972;176(5):597-604. doi:10.1097/00000658-197211000-00004

17. Harnchoowong S, Suchonwanit P. PPAR- $\gamma$ agonists and their role in primary cicatricial alopecia. PPAR Res. 2017;2017:2501248. doi: $10.1155 / 2017 / 2501248$

18. Ito T, Ito N, Bettermann A, Tokura Y, Takigawa M, Paus R. Collapse and restoration of MHC class-I-dependent immune privilege: exploiting the human hair follicle as a model. $\mathrm{Am}$ $J$ Pathol. 2004;164(2):623-634. doi:10.1016/S0002-9440(10) 63151-3

19. Suchonwanit P, Hector CE, Bin Saif GA, McMichael AJ. Factors affecting the severity of central centrifugal cicatricial alopecia. Int J Dermatol. 2016;55(6):e338-343. doi:10.1111/ijd.13061

20. Brocker EB, Echternacht-Happle K, Hamm H, Happle R. Abnormal expression of class I and class II major histocompatibility antigens in alopecia areata: modulation by topical immunotherapy. $J$ Invest Dermatol. 1987;88(5):564-568. doi:10.1111/1523-1747.ep12470166

21. Rosenblum MD, Yancey KB, Olasz EB, Truitt RL. CD200, a "no danger" signal for hair follicles. J Dermatol Sci. 2006;41 (3):165-174. doi:10.1016/j.jdermsci.2005.11.003

22. Bertolini M, Meyer KC, Slominski R, Kobayashi K, Ludwig RJ, Paus R. The immune system of mouse vibrissae follicles: cellular composition and indications of immune privilege. Exp Dermatol. 2013;22(9):593-598. doi:10.1111/exd.12205

23. Ito T, Ito N, Saatoff M, et al. Maintenance of hair follicle immune privilege is linked to prevention of $\mathrm{NK}$ cell attack. $J$ Invest Dermatol. 2008;128(5):1196-1206. doi:10.1038/sj.jid.5701183

24. Gilhar A, Kalish RS. Alopecia areata: a tissue specific autoimmune disease of the hair follicle. Autoimmun Rev. 2006;5 (1):64-69. doi:10.1016/j.autrev.2005.07.001

25. Subramanya RD, Coda AB, Sinha AA. Transcriptional profiling in alopecia areata defines immune and cell cycle control related genes within disease-specific signatures. Genomics. 2010;96 (3):146-153. doi:10.1016/j.ygeno.2010.05.002
26. Kang H, Wu WY, Lo BK, et al. Hair follicles from alopecia areata patients exhibit alterations in immune privilege-associated gene expression in advance of hair loss. $J$ Invest Dermatol. 2010;130 (11):2677-2680. doi:10.1038/jid.2010.180

27. Bertolini M, Zilio F, Rossi A, et al. Abnormal interactions between perifollicular mast cells and CD8+ T-cells may contribute to the pathogenesis of alopecia areata. PLoS One. 2014;9(5): e94260. doi:10.1371/journal.pone.0094260

28. Ito T, Suzuki T, Sakabe JI, Funakoshi A, Fujiyama T, Tokura Y. Plasmacytoid dendritic cells as a possible key player to initiate alopecia areata in the $\mathrm{C} 3 \mathrm{H} / \mathrm{HeJ}$ mouse. Allergol Int. 2020;69 (1):121-131. doi:10.1016/j.alit.2019.07.009

29. Xing L, Dai Z, Jabbari A, et al. Alopecia areata is driven by cytotoxic T lymphocytes and is reversed by JAK inhibition. Nat Med. 2014;20(9):1043-1049. doi:10.1038/nm.3645

30. McElwee KJ, Boggess D, King LE Jr, Sundberg JP. Experimental induction of alopecia areata-like hair loss in $\mathrm{C} 3 \mathrm{H} / \mathrm{HeJ}$ mice using full-thickness skin grafts. $J$ Invest Dermatol. 1998;111 (5):797-803. doi:10.1046/j.1523-1747.1998.00380.x

31. Gilhar A, Krueger GG. Hair growth in scalp grafts from patients with alopecia areata and alopecia universalis grafted onto nude mice. Arch Dermatol. 1987;123(1):44-50. doi:10.1001/ archderm.1987.01660250050016

32. Gilhar A, Landau M, Assy B, Shalaginov R, Serafimovich S, Kalish RS. Melanocyte-associated T cell epitopes can function as autoantigens for transfer of alopecia areata to human scalp explants on Prkdc(scid) mice. J Invest Dermatol. 2001;117 (6):1357-1362. doi:10.1046/j.0022-202x.2001.01583.x

33. Wang EHC, Yu M, Breitkopf T, et al. Identification of autoantigen epitopes in alopecia areata. J Invest Dermatol. 2016;136 (8):1617-1626. doi:10.1016/j.jid.2016.04.004

34. Leung MC, Sutton CW, Fenton DA, Tobin DJ. Trichohyalin is a potential major autoantigen in human alopecia areata. J Proteome Res. 2010;9(10):5153-5163. doi:10.1021/pr100422u

35. Paus R, Slominski A, Czarnetzki BM. Is alopecia areata an autoimmune-response against melanogenesis-related proteins, exposed by abnormal MHC class I expression in the anagen hair bulb? Yale J Biol Med. 1993;66(6):541-554.

36. Chanprapaph K, Udompanich S, Visessiri Y, Ngamjanyaporn P, Suchonwanit P. Nonscarring alopecia in systemic lupus erythematosus: a cross-sectional study with trichoscopic, histopathologic, and immunopathologic analyses. J Am Acad Dermatol. 2019;81(6):1319-1329. doi:10.1016/j.jaad.2019.05.053

37. Suchonwanit P, Udompanich S, Thadanipon K, Chanprapaph K. Trichoscopic signs in systemic lupus erythematosus: a comparative study with 109 patients and 305 healthy controls. J Eur Acad Dermatol Venereol. 2019;33(4):774-780. doi:10.1111/jdv.15421

38. Pratt $\mathrm{CH}$, King LE Jr, Messenger AG, Christiano AM, Sundberg JP. Alopecia areata. Nat Rev Dis Primers. 2017;3:17011. doi:10.1038/nrdp.2017.11

39. Gilhar A, Etzioni A, Paus R. Alopecia areata. $N$ Engl J Med. 2012;366(16):1515-1525. doi:10.1056/NEJMra1103442

40. de Jong A, Jabbari A, Dai $Z$, et al. High-throughput $\mathrm{T}$ cell receptor sequencing identifies clonally expanded CD8+ T cell populations in alopecia areata. JCI Insight. 2018;3(19). doi:10.1172/jci.insight.121949.

41. McElwee KJ, Freyschmidt-Paul P, Hoffmann R, et al. Transfer of CD8(+) cells induces localized hair loss whereas CD4(+)/CD25(-) cells promote systemic alopecia areata and $\mathrm{CD} 4(+) / \mathrm{CD} 25(+)$ cells blockade disease onset in the $\mathrm{C} 3 \mathrm{H} / \mathrm{HeJ}$ mouse model. $J$ Invest Dermatol. 2005;124(5):947-957. doi:10.1111/j.0022202X.2005.23692.x

42. Gilhar A, Keren A, Shemer A, d'Ovidio R, Ullmann Y, Paus R. Autoimmune disease induction in a healthy human organ: a humanized mouse model of alopecia areata. $J$ Invest Dermatol. 2013;133(3):844-847. doi:10.1038/jid.2012.365 
43. Ebrahim AA, Salem RM, El Fallah AA, Younis ET. Serum Interleukin-15 is a Marker of Alopecia Areata Severity. Int J Trichology. 2019;11(1):26-30. doi:10.4103/ijt.ijt_80_18

44. Fuentes-Duculan J, Gulati N, Bonifacio KM, et al. Biomarkers of alopecia areata disease activity and response to corticosteroid treatment. Exp Dermatol. 2016;25(4):282-286. doi:10.1111/ exd. 12918

45. Ghoreishi M, Martinka M, Dutz JP. Type 1 interferon signature in the scalp lesions of alopecia areata. Br J Dermatol. 2010;163 (1):57-62. doi:10.1111/j.1365-2133.2010.09775.x

46. McPhee CG, Duncan FJ, Silva KA, et al. Increased expression of Cxcr3 and its ligands, Cxc19 and Cxcl10, during the development of alopecia areata in the mouse. J Invest Dermatol. 2012;132 (6):1736-1738. doi:10.1038/jid.2012.17

47. Villasante Fricke AC, Miteva M. Epidemiology and burden of alopecia areata: a systematic review. Clin Cosmet Investig Dermatol. 2015;8:397-403.

48. Tanemura A, Oiso N, Nakano M, Itoi S, Kawada A, Katayama I. Alopecia areata: infiltration of Th17 cells in the dermis, particularly around hair follicles. Dermatology. 2013;226(4):333-336. doi: $10.1159 / 000350933$

49. Lee GR. The balance of Th17 versus treg cells in autoimmunity. Int J Mol Sci. 2018;19(3):730.

50. Othy S, Jairaman A, Dynes JL, et al. Regulatory T cells suppress Th17 cell $\mathrm{Ca}(2+)$ signaling in the spinal cord during murine autoimmune neuroinflammation. Proc Natl Acad Sci U S A. 2020;117(33):20088-20099. doi:10.1073/pnas.2006895117

51. Loh SH, Moon HN, Lew BL, Sim WY. Role of T helper 17 cells and $\mathrm{T}$ regulatory cells in alopecia areata: comparison of lesion and serum cytokine between controls and patients. J Eur Acad Dermatol Venereol. 2018;32(6):1028-1033. doi:10.1111/ jdv. 14775

52. Ghoreschi K, Laurence A, Yang XP, Hirahara K, O'Shea JJ. $\mathrm{T}$ helper 17 cell heterogeneity and pathogenicity in autoimmune disease. Trends Immunol. 2011;32(9):395-401. doi:10.1016/j. it.2011.06.007

53. Noack M, Miossec P. Th17 and regulatory $\mathrm{T}$ cell balance in autoimmune and inflammatory diseases. Autoimmun Rev. 2014;13(6):668-677. doi:10.1016/j.autrev.2013.12.004

54. Han YM, Sheng YY, Xu F, et al. Imbalance of T-helper 17 and regulatory $\mathrm{T}$ cells in patients with alopecia areata. $J$ Dermatol. 2015;42(10):981-988. doi:10.1111/1346-8138.12978

55. Abou Rahal J, Kurban M, Kibbi AG, Abbas O. Plasmacytoid dendritic cells in alopecia areata: missing link? J Eur Acad Dermatol Venereol. 2016;30(1):119-123. doi:10.1111/jdv.12932

56. Saadeh D, Kurban M, Abbas O. Update on the role of plasmacytoid dendritic cells in inflammatory/autoimmune skin diseases. Exp Dermatol. 2016;25(6):415-421. doi:10.1111/exd.12957

57. McKenna K, Beignon AS, Bhardwaj N. Plasmacytoid dendritic cells: linking innate and adaptive immunity. $J$ Virol. 2005;79 (1):17-27. doi:10.1128/JVI.79.1.17-27.2005

58. Paus R, Bulfone-Paus S, Bertolini M. Hair follicle immune privilege revisited: the key to alopecia areata management. J Investig Dermatol Symp Proc. 2018;19(1):S12-S17. doi:10.1016/j. jisp.2017.10.014

59. Sundberg JP, Boggess D, Montagutelli X, Hogan ME, King LE Jr. $\mathrm{C} 3 \mathrm{H} / \mathrm{HeJ}$ mouse model for alopecia areata. J Invest Dermatol. 1995;104(5 Suppl):16S-17S. doi:10.1038/jid.1995.38

60. Freyschmidt-Paul P, McElwee KJ, Hoffmann R, et al. Interferongamma-deficient mice are resistant to the development of alopecia areata. Br J Dermatol. 2006;155(3):515-521. doi:10.1111/j.13652133.2006.07377.x

61. Nakamura M, Jo J, Tabata Y, Ishikawa O. Controlled delivery of T-box21 small interfering RNA ameliorates autoimmune alopecia (Alopecia Areata) in a $\mathrm{C} 3 \mathrm{H} / \mathrm{HeJ}$ mouse model. Am J Pathol. 2008;172(3):650-658. doi:10.2353/ajpath.2008.061249
62. Arca E, Musabak U, Akar A, Erbil AH, Tastan HB. Interferongamma in alopecia areata. Eur J Dermatol. 2004;14(1):33-36.

63. Triyangkulsri K, Suchonwanit P. Role of janus kinase inhibitors in the treatment of alopecia areata. Drug Des Devel Ther. 2018;12:2323-2335. doi:10.2147/DDDT.S172638

64. Thein C, Strange P, Hansen ER, Baadsgaard O. Lesional alopecia areata $\mathrm{T}$ lymphocytes downregulate epithelial cell proliferation. Arch Dermatol Res. 1997;289(7):384-388. doi:10.1007/s004030050209

65. Kasumagic-Halilovic E, Prohic A, Cavaljuga S. Tumor necrosis factor-alpha in patients with alopecia areata. Indian J Dermatol. 2011;56(5):494-496. doi:10.4103/0019-5154.87124

66. Hoffmann R, Eicheler W, Huth A, Wenzel E, Happle R. Cytokines and growth factors influence hair growth in vitro. Possible implications for the pathogenesis and treatment of alopecia areata. Arch Dermatol Res. 1996;288(3):153-156. doi:10.1007/BF02505825

67. Kollias G, Kontoyiannis D. Role of TNF/TNFR in autoimmunity: specific TNF receptor blockade may be advantageous to anti-TNF treatments. Cytokine Growth Factor Rev. 2002;13(4-5):315-321. doi:10.1016/S1359-6101(02)00019-9

68. Galbraith GM, Pandey JP. Tumor necrosis factor alpha (TNF-alpha) gene polymorphism in alopecia areata. Hum Genet. 1995;96(4):433-436. doi:10.1007/BF00191802

69. Suchonwanit P, Chalermroj N, Khunkhet S. Low-level laser therapy for the treatment of androgenetic alopecia in Thai men and women: a 24-week, randomized, double-blind, sham device-controlled trial. Lasers Med Sci. 2019;34(6):1107-1114. doi:10.1007/s10103-018-02699-9

70. Paus R, Nickoloff BJ, Ito T. A 'hairy' privilege. Trends Immunol. 2005;26(1):32-40. doi:10.1016/j.it.2004.09.014

71. Groom JR, Luster AD. CXCR3 ligands: redundant, collaborative and antagonistic functions. Immunol Cell Biol. 2011;89 (2):207-215. doi:10.1038/icb.2010.158

72. Rotondi M, Chiovato L, Romagnani S, Serio M, Romagnani P. Role of chemokines in endocrine autoimmune diseases. Endocr Rev. 2007;28(5):492-520. doi:10.1210/er.2006-0044

73. Dai Z, Xing L, Cerise J, et al. CXCR3 blockade inhibits $\mathrm{T}$ cell migration into the skin and prevents development of alopecia areata. J Immunol. 2016;197(4):1089-1099. doi:10.4049/jimmunol.1501798

74. Suarez-Farinas M, Ungar B, Noda S, et al. Alopecia areata profiling shows TH1, TH2, and IL-23 cytokine activation without parallel TH17/TH22 skewing. J Allergy Clin Immunol. 2015;136 (5):1277-1287. doi:10.1016/j.jaci.2015.06.032

75. McElwee KJ, Hoffmann R. Alopecia areata - animal models. Clin Exp Dermatol. 2002;27(5):410-417. doi:10.1046/j.13652230.2002.01075.x

76. Chu SY, Chen YJ, Tseng WC, et al. Comorbidity profiles among patients with alopecia areata: the importance of onset age, a nationwide population-based study. J Am Acad Dermatol. 2011;65(5):949-956. doi:10.1016/j.jaad.2010.08.032

77. Attia EA, El Shennawy D, Sefin A. Serum interleukin-4 and total immunoglobulin E in nonatopic alopecia areata patients and HLA-DRB1 typing. Dermatol Res Pract. 2010;2010:503587. doi:10.1155/2010/503587

78. Song $\mathrm{T}$, Pavel AB, Wen $\mathrm{HC}$, et al. An integrated model of alopecia areata biomarkers highlights both $\mathrm{TH} 1$ and $\mathrm{TH} 2$ upregulation. J Allergy Clin Immunol. 2018;142(5):1631-1634 e1613. doi:10.1016/j.jaci.2018.06.029

79. Inui S, Noguchi F, Nakajima T, Itami S. Serum thymus and activation-regulated chemokine as disease activity and response biomarker in alopecia areata. J Dermatol. 2013;40(11):881-885. doi:10.1111/1346-8138.12273

80. Kanokrungsee S, Anuntrangsee T, Tankunakorn J, Srisuwanwattana P, Suchonwanit P, Chanprapaph K. Rituximab therapy for treatment of pemphigus in Southeast Asians. Drug Des Devel Ther. 2021;15:1677-1690. doi:10.2147/DDDT.S306046 
81. Muller SA, Winkelmann RK. Alopecia areata. an evaluation of 736 patients. Arch Dermatol. 1963;88:290-297. doi:10.1001/ archderm.1963.01590210048007

82. Shellow WV, Edwards JE, Koo JY. Profile of alopecia areata: a questionnaire analysis of patient and family. Int $J$ Dermatol. 1992;31(3):186-189. doi:10.1111/j.1365-4362.1992.tb03932.x

83. Suchonwanit P, Triamchaisri S, Wittayakornrerk S, Rattanakaemakorn P. Leprosy reaction in thai population: a 20-year retrospective study. Dermatol Res Pract. 2015;2015:253154. doi:10.1155/2015/253154

84. Boonsakan P, Iamsumang W, Chantrathammachart P, Chayavichitsilp P, Suchonwanit P, Rutnin S. Prognostic value of concurrent expression of C-MYC and BCL2 in intravascular large B-cell lymphoma: a 10-year retrospective study. Biomed Res Int. 2020;2020:1350820. doi:10.1155/2020/1350820

85. Blaumeiser B, van der Goot I, Fimmers R, et al. Familial aggregation of alopecia areata. J Am Acad Dermatol. 2006;54 (4):627-632. doi:10.1016/j.jaad.2005.12.007

86. Jackow C, Puffer N, Hordinsky M, Nelson J, Tarrand J, Duvic M. Alopecia areata and cytomegalovirus infection in twins: genes versus environment? J Am Acad Dermatol. 1998;38(3):418-425. doi:10.1016/S0190-9622(98)70499-2

87. Rodriguez TA, Fernandes KE, Dresser KL, Duvic M; National Alopecia Areata R. Concordance rate of alopecia areata in identical twins supports both genetic and environmental factors. $J$ Am Acad Dermatol. 2010;62(3):525-527. doi:10.1016/j.jaad.2009.02.006

88. Kungvalpivat $\mathrm{P}$, Rojhirunsakool S, Chayavichitsilp P, Suchonwanit P, Wichayachakorn CT, Rutnin S. Clinical and onychoscopic features of benign and malignant conditions in longitudinal melanonychia in the thai population: a comparative analysis. Clin Cosmet Investig Dermatol. 2020;13:857-865. doi: 10.2147/CCID.S283112

89. Colombe BW, Price VH, Khoury EL, Garovoy MR, Lou CD. HLA class II antigen associations help to define two types of alopecia areata. J Am Acad Dermatol. 1995;33(5 Pt 1):757-764.

90. Sundberg JP, Silva KA, Li R, Cox GA, King LE. Adult-onset Alopecia areata is a complex polygenic trait in the $\mathrm{C} 3 \mathrm{H} / \mathrm{HeJ}$ mouse model. J Invest Dermatol. 2004;123(2):294-297. doi:10.1111/j.0022-202X.2004.23222.x

91. Barahmani N, de Andrade M, Slusser JP, Zhang Q, Duvic M. Major histocompatibility complex class I chain-related gene A polymorphisms and extended haplotypes are associated with familial alopecia areata. J Invest Dermatol. 2006;126(1):74-78. doi:10.1038/sj.jid.5700009

92. Petukhova L, Duvic M, Hordinsky M, et al. Genome-wide association study in alopecia areata implicates both innate and adaptive immunity. Nature. 2010;466(7302):113-117. doi:10.1038/nature09114

93. Jagielska D, Redler S, Brockschmidt FF, et al. Follow-up study of the first genome-wide association scan in alopecia areata: IL13 and KIAA0350 as susceptibility loci supported with genome-wide significance. $J$ Invest Dermatol. 2012;132(9):2192-2197. doi:10.1038/jid.2012.129

94. Kemp EH, McDonagh AJ, Wengraf DA, et al. The non-synonymous C1858T substitution in the PTPN22 gene is associated with susceptibility to the severe forms of alopecia areata. Hum Immunol. 2006;67(7):535-539. doi:10.1016/j. humimm.2006.04.006

95. Arck PC, Handjiski B, Peters EM, et al. Stress inhibits hair growth in mice by induction of premature catagen development and deleterious perifollicular inflammatory events via neuropeptide substance P-dependent pathways. Am J Pathol. 2003;162 (3):803-814. doi:10.1016/S0002-9440(10)63877-1

96. Chanprapaph K, Sutharaphan T, Suchonwanit P. Scalp biophysical characteristics in males with androgenetic alopecia: a comparative study with healthy controls. Clin Interv Aging. 2021;16:781-787. doi:10.2147/CIA.S310178
97. Peters EM, Handjiski B, Kuhlmei A, et al. Neurogenic inflammation in stress-induced termination of murine hair growth is promoted by nerve growth factor. Am J Pathol. 2004;165 (1):259-271. doi:10.1016/S0002-9440(10)63294-4

98. Theoharides TC, Donelan JM, Papadopoulou N, Cao J, Kempuraj D, Conti P. Mast cells as targets of corticotropin-releasing factor and related peptides. Trends Pharmacol Sci. 2004;25(11):563-568. doi:10.1016/j. tips.2004.09.007

99. Suchonwanit P, Iamsumang W, Rojhirunsakool S. Efficacy of topical combination of $0.25 \%$ finasteride and $3 \%$ minoxidil versus $3 \%$ minoxidil solution in female pattern hair loss: a randomized, double-blind, controlled study. Am J Clin Dermatol. 2019;20 (1):147-153. doi:10.1007/s40257-018-0387-0

100. Suchonwanit P, Srisuwanwattana P, Chalermroj N, Khunkhet S. A randomized, double-blind controlled study of the efficacy and safety of topical solution of $0.25 \%$ finasteride admixed with $3 \%$ minoxidil vs. $3 \%$ minoxidil solution in the treatment of male androgenetic alopecia. J Eur Acad Dermatol Venereol. 2018;32 (12):2257-2263. doi:10.1111/jdv.15171

101. Suchonwanit P, Rojhirunsakool S, Khunkhet S. A randomized, investigator-blinded, controlled, split-scalp study of the efficacy and safety of a 1550-nm fractional erbium-glass laser, used in combination with topical 5\% minoxidil versus 5\% minoxidil alone, for the treatment of androgenetic alopecia. Lasers Med Sci. 2019;34(9):1857-1864. doi:10.1007/s10103-019-02783-8

102. Skinner RB Jr, Light WH, Bale GF, Rosenberg EW, Leonardi C. Alopecia areata and presence of cytomegalovirus DNA. JAMA. 1995;273(18):1419-1420. doi:10.1001/jama.1995.035204200 31025

103. Tosti A, La Placa M, Placucci F, et al. No correlation between cytomegalovirus and alopecia areata. J Invest Dermatol. 1996;107 (3):443. doi:10.1111/1523-1747.ep12365508

104. Rodriguez TA, Duvic M; National Alopecia Areata R. Onset of alopecia areata after Epstein-Barr virus infectious mononucleosis. J Am Acad Dermatol. 2008;59(1):137-139. doi:10.1016/j. jaad.2008.02.005

105. Ito $\mathrm{T}$, Tokura Y. Alopecia areata triggered or exacerbated by swine flu virus infection. J Dermatol. 2012;39(10):863-864. doi:10.1111/j.1346-8138.2011.01437.x

106. Jin W, Zheng H, Shan B, Wu Y. Changes of serum trace elements level in patients with alopecia areata: a meta-analysis. $J$ Dermatol. 2017;44(5):588-591. doi:10.1111/1346-8138.13705

107. Abdel Fattah NS, Atef MM, Al-Qaradaghi SM. Evaluation of serum zinc level in patients with newly diagnosed and resistant alopecia areata. Int J Dermatol. 2016;55(1):24-29. doi:10.1111/ ijd.12769

108. Wise RP, Kiminyo KP, Salive ME. Hair loss after routine immunizations. JAMA. 1997;278(14):1176-1178. doi:10.1001/ jama.1997.03550140068042

109. Sundberg JP, Silva KA, Zhang W, et al. Recombinant human hepatitis B vaccine initiating alopecia areata: testing the hypothesis using the C3H/HeJ mouse model. Vet Dermatol. 2009;20 (2):99-104. doi:10.1111/j.1365-3164.2008.00692.x

110. Huang KP, Mullangi S, Guo Y, Qureshi AA. Autoimmune, atopic, and mental health comorbid conditions associated with alopecia areata in the United States. JAMA Dermatol. 2013;149 (7):789-794. doi:10.1001/jamadermatol.2013.3049

111. Magen E, Chikovani T, Waitman DA, Kahan NR. Association of alopecia areata with atopic dermatitis and chronic spontaneous urticaria. Allergy Asthma Proc. 2018;39(2):96-102. doi:10.2500/ aap.2018.39.4114

112. Li SF, Zhang XT, Qi SL, et al. Allergy to dust mites may contribute to early onset and severity of alopecia areata. Clin Exp Dermatol. 2015;40(2):171-176. doi:10.1111/ced.12471 
113. Shapiro J. Current treatment of alopecia areata. J Investig Dermatol Symp Proc. 2013;16(1):S42-44. doi:10.1038/ jidsymp.2013.14

114. Rattananukrom T, Suchonwanit P. Are drug treatment strategies really effective against alopecia areata? Expert Opin Pharmacother. 2021;22(3):257-260. doi:10.1080/14656566.20 20.1854728

115. Zoller M, McElwee KJ, Vitacolonna M, Hoffmann R. The progressive state, in contrast to the stable or regressive state of alopecia areata, is reflected in peripheral blood mononuclear cells. Exp Dermatol. 2004;13(7):435-444. doi:10.1111/j.09066705.2004.00179.x

116. Manimaran RP, Ramassamy S, Rajappa M, Chandrashekar L. Therapeutic outcome of diphencyprone and its correlation with serum cytokine profile in alopecia areata. $J$ Dermatolog Treat. 2020;1-5. doi:10.1080/09546634.2020.1752887

117. Kuwano Y, Fujimoto M, Watanabe R, et al. Serum chemokine profiles in patients with alopecia areata. Br J Dermatol. 2007;157 (3):466-473. doi:10.1111/j.1365-2133.2007.07943.x

118. Konig A, Happle R, Hoffmann R. IFN-gamma-induced HLA-DR but not ICAM-1 expression on cultured dermal papilla cells is downregulated by TNF-alpha. Arch Dermatol Res. 1997;289 (8):466-470. doi:10.1007/s004030050222

119. Happle R, Hausen BM, Wiesner-Menzel L. Diphencyprone in the treatment of alopecia areata. Acta Derm Venereol. 1983;63 (1):49-52.

120. Messenger AG, McKillop J, Farrant P, McDonagh AJ, Sladden M. British Association of Dermatologists' guidelines for the management of alopecia areata 2012. Br J Dermatol. 2012;166(5):916-926. doi:10.1111/j.1365-2133.2012.10955.x

121. Mahasaksiri T, Kositkuljorn C, Anuntrangsee T, Suchonwanit P. Application of topical immunotherapy in the treatment of alopecia areata: a review and update. Drug Des Devel Ther. 2021;15:1285-1298. doi:10.2147/DDDT.S297858

122. Durdu M, Ozcan D, Baba M, Seckin D. Efficacy and safety of diphenylcyclopropenone alone or in combination with anthralin in the treatment of chronic extensive alopecia areata: a retrospective case series. $J$ Am Acad Dermatol. 2015;72(4):640-650. doi:10.1016/j.jaad.2015.01.008

123. Ibrahim SA, Esawy AM, Abdelshafy AS. Treatment of chronic extensive alopecia areata by diphenylcyclopropenone alone versus in combination with anthralin. Dermatol Ther. 2019;32(5): e13010. doi:10.1111/dth.13010

124. Kagami S, Kishi Y, Hino H. Topical immunotherapy in combination with anthralin in the treatment of refractory alopecia areata. $J$ Cosmet Dermatol. 2020;19(9):2411-2414. doi:10.1111/ jocd. 13588

125. Nasimi M, Ghandi N, Abedini R, Mirshamsi A, Shakoei S, Seirafi H. Efficacy and safety of anthralin in combination with diphenylcyclopropenone in the treatment of alopecia areata: a retrospective case series. Arch Dermatol Res. 2019;311 (8):607-613. doi:10.1007/s00403-019-01940-x

126. Shapiro J, Tan J, Ho V, Abbott F, Tron V. Treatment of chronic severe alopecia areata with topical diphenylcyclopropenone and 5\% minoxidil: a clinical and immunopathologic evaluation. $\mathrm{J} \mathrm{Am}$ Acad Dermatol. 1993;29(5 Pt 1):729-735. doi:10.1016/01909622(93)70238-O

127. Wasylyszyn T, Borowska K. Possible advantage of imiquimod and diphenylcyclopropenone combined treatment versus diphenylcyclopropenone alone: an observational study of nonresponder patients with alopecia areata. Australas J Dermatol. 2017;58 (3):219-223. doi:10.1111/ajd.12478

128. Sriphojanart T, Khunkhet S, Suchonwanit P. A retrospective comparative study of the efficacy and safety of two regimens of diphenylcyclopropenone in the treatment of recalcitrant alopecia areata. Dermatol Rep. 2017;9(2):7399. doi:10.4081/dr.2017.7399
129. Thuangtong R, Varothai S, Triwongwaranat D, Rujitharanawong C. Multi-concentration level patch test guided diphenyl cyclopropenone (DPCP) treatment in alopecia totalis or alopecia universalis. J Med Assoc Thai. 2017;100(1):86-92.

130. Lee S, Lee WS. Home-based contact immunotherapy with diphenylcyclopropenone for alopecia areata is as effective and safe as clinic-based treatment in patients with stable disease: a retrospective study of 40 patients. J Am Acad Dermatol. 2018;78(3):599-601.e591. doi:10.1016/j.jaad.2017.09.037

131. Nowicka D, Maj J, Jankowska-Konsur A, Hryncewicz-Gwozdz A. Efficacy of diphenylcyclopropenone in alopecia areata: a comparison of two treatment regimens. Postepy Dermatol Alergol. 2018;35(6):577-581. doi:10.5114/ada.2018.77608

132. Kim BJ, Lee S, Lee CH, Lee WS. Home-based contact immunotherapy with diphenylcyclopropenone improves compliance with the recommended follow-up for patients with alopecia areata: a retrospective cohort study. $J$ Am Acad Dermatol. 2020;82(5):1223-1225. doi:10.1016/j.jaad.2019.10.043

133. Leonard WJ, O'Shea JJ. Jaks and STATs: biological implications. Annu Rev Immunol. 1998;16:293-322. doi:10.1146/annurev. immunol.16.1.293

134. Schwartz DM, Kanno Y, Villarino A, Ward M, Gadina M, O'Shea JJ. JAK inhibition as a therapeutic strategy for immune and inflammatory diseases. Nat Rev Drug Discov. 2017;17(1):78. doi:10.1038/nrd.2017.267

135. Harel S, Higgins CA, Cerise JE, et al. Pharmacologic inhibition of JAK-STAT signaling promotes hair growth. Sci Adv. 2015;1(9): e1500973. doi:10.1126/sciadv. 1500973

136. Rajabi F, Drake LA, Senna MM, Rezaei N. Alopecia areata: a review of disease pathogenesis. Br J Dermatol. 2018;179 (5):1033-1048.

137. Forero-Pena DA, Gutierrez FR. Statins as modulators of regulatory T-cell biology. Mediators Inflamm. 2013;2013:167086. doi:10.1155/2013/167086

138. Cervantes J, Jimenez JJ, DelCanto GM, Tosti A. Treatment of alopecia areata with simvastatin/ezetimibe. J Investig Dermatol Symp Proc. 2018;19(1):S25-S31. doi:10.1016/j.jisp.2017.10.013

139. Choi JW, Suh DW, Lew BL, Sim WY. Simvastatin/ezetimibe therapy for recalcitrant alopecia areata: an open prospective study of 14 patients. Ann Dermatol. 2017;29(6):755-760. doi:10.5021/ad.2017.29.6.755

140. Loi C, Starace M, Piraccini BM. Alopecia areata (AA) and treatment with simvastatin/ezetimibe: experience of 20 patients. $\mathrm{J} \mathrm{Am} \mathrm{Acad}$ Dermatol. 2016;74(5):e99-e100. doi:10.1016/j.jaad.2015.09.071

141. Lattouf C, Jimenez JJ, Tosti A, et al. Treatment of alopecia areata with simvastatin/ezetimibe. J Am Acad Dermatol. 2015;72 (2):359-361. doi:10.1016/j.jaad.2014.11.006

142. Poole RM, Ballantyne AD. Apremilast: first global approval. Drugs. 2014;74(7):825-837. doi:10.1007/s40265-014-0218-4

143. Keren A, Shemer A, Ullmann Y, Paus R, Gilhar A. The PDE4 inhibitor, apremilast, suppresses experimentally induced alopecia areata in human skin in vivo. $J$ Dermatol Sci. 2015;77(1):74-76. doi:10.1016/j.jdermsci.2014.11.009

144. Mikhaylov D, Pavel A, Yao C, et al. A randomized placebo-controlled single-center pilot study of the safety and efficacy of apremilast in subjects with moderate-to-severe alopecia areata. Arch Dermatol Res. 2019;311(1):29-36. doi:10.1007/ s00403-018-1876-y

145. Liu LY, King BA. Lack of efficacy of apremilast in 9 patients with severe alopecia areata. J Am Acad Dermatol. 2017;77 (4):773-774. doi:10.1016/j.jaad.2017.05.034

146. Zorn E, Nelson EA, Mohseni M, et al. IL-2 regulates FOXP3 expression in human $\mathrm{CD} 4+\mathrm{CD} 25+$ regulatory $\mathrm{T}$ cells through a STAT-dependent mechanism and induces the expansion of these cells in vivo. Blood. 2006;108(5):1571-1579. doi:10.1182/blood2006-02-004747 
147. Castela E, Le Duff F, Butori C, et al. Effects of low-dose recombinant interleukin 2 to promote T-regulatory cells in alopecia areata. JAMA Dermatol. 2014;150(7):748-751. doi:10.1001/ jamadermatol.2014.504

148. Hordinsky M, Kaplan DH. Low-dose interleukin 2 to reverse alopecia areata. JAMA Dermatol. 2014;150(7):696-697. doi:10.1001/jamadermatol.2014.510

149. Skurkovich S, Korotky NG, Sharova NM, Skurkovich B. Treatment of alopecia areata with anti-interferon-gamma antibodies. $J$ Investig Dermatol Symp Proc. 2005;10 (3):283-284. doi:10.1111/j.0022-202X.2005.10130_6.x

150. Strober BE, Siu K, Alexis AF, et al. Etanercept does not effectively treat moderate to severe alopecia areata: an open-label study. $J$ Am Acad Dermatol. 2005;52(6):1082-1084. doi:10.1016/j.jaad.2005.03.039

151. Abramovits W, Losornio M. Failure of two TNF-alpha blockers to influence the course of alopecia areata. Skinmed. 2006;5 (4):177-181. doi:10.1111/j.1540-9740.2006.05443.x

152. Exarchou SA, Voulgari PV, Markatseli TE, Zioga A, Drosos AA. Immune-mediated skin lesions in patients treated with anti-tumour necrosis factor alpha inhibitors. Scand J Rheumatol. 2009;38(5):328-331. doi:10.1080/03009740902922612

153. Slowinska M, Kardynal A, Warszawik O, Czuwara J, Rudnicka L. Alopecia areata developing paralell to improvement of psoriasis during ustekinumab therapy. J Dermatol Case Rep. 2010;4 (1):15-17. doi:10.3315/jdcr.2010.1041

154. Guttman-Yassky E, Ungar B, Noda S, et al. Extensive alopecia areata is reversed by IL-12/IL-23p40 cytokine antagonism. J Allergy Clin Immunol. 2016;137(1):301-304. doi:10.1016/j. jaci.2015.11.001

155. Aleisa A, Lim Y, Gordon S, et al. Response to ustekinumab in three pediatric patients with alopecia areata. Pediatr Dermatol. 2019;36(1):e44-e45. doi:10.1111/pde.13699

156. Verros C, Rallis E, Crowe M. Letter: alopecia areata during ustekinumab administration: co-existence or an adverse reaction? Dermatol Online J. 2012;18(7):14. doi:10.5070/ D34G31C0TM

157. Strober BE, Menon K. Alefacept for the treatment of psoriasis and other dermatologic diseases. Dermatol Ther. 2007;20 (4):270-276. doi:10.1111/j.1529-8019.2007.00140.x

158. Bui K, Polisetty S, Gilchrist H, Jackson SM, Frederic J. Successful treatment of alopecia universalis with alefacept: a case report and review of the literature. Cutis. 2008;81 (5):431-434.
159. Strober BE, Menon K, McMichael A, et al. Alefacept for severe alopecia areata: a randomized, double-blind, placebo-controlled study. Arch Dermatol. 2009;145(11):1262-1266. doi:10.1001/ archdermatol.2009.264

160. Kaelin U, Hassan AS, Braathen LR, Yawalkar N. Treatment of alopecia areata partim universalis with efalizumab. $\mathrm{J} \mathrm{Am} \mathrm{Acad}$ Dermatol. 2006;55(3):529-532. doi:10.1016/j.jaad.2006.05.062

161. Smith JR, Akin RS, Wells MJ. Alopecia areata treated with efalizumab: a case with significant hair re-growth after long-term therapy. J Drugs Dermatol. 2009;8(8):758-760.

162. Price VH, Hordinsky MK, Olsen EA, et al. Subcutaneous efalizu$\mathrm{mab}$ is not effective in the treatment of alopecia areata. $\mathrm{J} \mathrm{Am} \mathrm{Acad}$ Dermatol. 2008;58(3):395-402. doi:10.1016/j.jaad.2007.10.645

163. Udompanich S, Chanprapaph K, Suchonwanit P. Hair and scalp changes in cutaneous and systemic lupus erythematosus. $\mathrm{Am}$ J Clin Dermatol. 2018;19(5):679-694. doi:10.1007/s40257-0180363-8

164. Iamsumang W, Leerunyakul K, Suchonwanit P. Finasteride and its potential for the treatment of female pattern hair loss: evidence to date. Drug Des Devel Ther. 2020;14:951-959. doi:10.2147/ DDDT.S240615

165. Leerunyakul K, Suchonwanit P. Evaluation of hair density and hair diameter in the adult thai population using quantitative trichoscopic analysis. Biomed Res Int. 2020;2020:2476890. doi:10.1155/2020/2476890

166. Suchonwanit P, McMichael AJ. Alopecia in association with malignancy: a review. Am J Clin Dermatol. 2018;19 (6):853-865. doi:10.1007/s40257-018-0378-1

167. Rattanakaemakorn P, Triyangkulsri K, Iamsumang W, Suchonwanit P. 308-nm excimer lamp vs. Combination of 308-nm excimer lamp and 10\% liquor carbonis detergens in patients with scalp psoriasis: a randomized, single-blinded, controlled trial. Front Med (Lausanne). 2021;8:677948. doi:10.3389/ fmed.2021.677948

168. Chanprapaph K, Fakprapai W, Limtong P, Suchonwanit P. Nailfold capillaroscopy with USB digital microscopy in connective tissue diseases: a comparative study of 245 patients and healthy controls. Front Med (Lausanne). 2021;8:683900. doi:10.3389/fmed.2021.683900

169. Rattanakaemakorn $P$, Pinyowiwat $P$, Iamsumang W, Chanprapaph K, Suchonwanit P. Incidence and risk factors of hepatic fibrosis in psoriatic patients receiving methotrexate with concomitant acitretin therapy and methotrexate monotherapy. Drug Des Devel Ther. 2021;15:2299-2307. doi:10.2147/DDDT.S304168
ImmunoTargets and Therapy

\section{Publish your work in this journal}

ImmunoTargets and Therapy is an international, peer-reviewed open access journal focusing on the immunological basis of diseases, potential targets for immune based therapy and treatment protocols employed to improve patient management. Basic immunology and physiology of the immune system in health, and disease will be also covered. In addition, the journal will focus on the impact of management programs and new therapeutic agents and protocols on patient perspectives such as quality of life, adherence and satisfaction. The manuscript management system is completely online and includes a very quick and fair peer-review system, which is all easy to use. Visit http://www.dovepress.com/testimonials.php to read real quotes from published authors. 